\title{
SOCIO-ECONOMIC SITUATION IN TURKESTAN VILLAGES AFTER THE ESTABLISHMENT OF SOVIET GOVERNMENT
}

\author{
Feruza Rakhmanovna Isakova \\ Doctor of Philosophy in History (PhD), Senior lecturer at the Department of "World History" \\ of Andizhan State University, Andizhan region, Republic of Uzbekistan
}

Article DOI: https://doi.org/10.36713/epra9194

DOI No: 10.36713/epra9194

\begin{abstract}
The article describes the changes that took place in the social structure of the village of Turkestan at the beginning of the establishment of Soviet power, the dominance in agriculture of still individual small peasant farms. Formation of new social strata - collective farms and state farm workers, associated with new economic sectors of the economy - collective farms and state farms.

KEY WORDS: village, farmer, farm, livestock, Turkestan, alienation, population, government, industry, poor, middle peasant, rich, religion, apparatus, individual farmer.
\end{abstract}

\section{INTRODUCTION}

In 1917, the rural population of Turkestan numbered 5,335,600 people and accounted for $83.6 \%$ of the total population [1]. By this time, his economic situation had deteriorated significantly. With the outbreak of World War I, the tsarist government challenged the Russian cotton industry to supply the army with fabrics at reasonable prices and set firm purchasing prices for cotton fiber, which did not even cover the cost of growing it. A situation arose when it became simply not profitable for farmers to grow this crop, which was previously very profitable for them. Since 1916, in Turkestan, a decrease in the sown areas of cotton began, and by 1917 they had already decreased, in comparison with 1915 , by $20 \%$. This was facilitated by the disruption of transport communication between the region and the central regions of Russia, caused by the war, and, consequently, a decrease in the amount of imported grain, which forced many farmers to switch to sowing grain and fodder crops. Cotton began to gradually lose its dominant position in agriculture in the region. If in the pre-war period in the total amount of agricultural products grown in Turkestan, food crops accounted for $35.8 \%$, fodder crops - $14 \%$, industrial crops $-50.2 \%$ (including cotton - 49.1\%), then in 1917 the cultivation of food crops increased to $48.6 \%$, fodder crops - up to $21.6 \%$, and technical crops decreased to $29.8 \%$ (including cotton - up to $29.1 \%$ ) [2]. The region's agriculture lost its commercial character and gradually began to turn into a natural-consumer one.

\section{METHODS}

They completed the destructive processes of the First World War - the uprising of 1916 and its brutal suppression, drought and poor harvest in 1917. They caused a reduction in the number of livestock, sown areas of not only cotton, but also grain crops. In the village, there was a clear tendency towards impoverishment. This is confirmed by a comparative analysis of the materials of the revision of the region by Count K. Palen in 1909 and the data of the agricultural census of 1917.

\section{RESULTS AND DISCUSSIONS}

It shows that in 1917 in the Turkestan peasant there were $43.9 \%$ of the poor, $51.9 \%$ of the average, $4.2 \%$ of the rich peasant farms. Compared to 1909 , the number of landless farmers in it increased significantly and the number of poor people in general increased, while the number of well-to-do 


\section{SJIF Impact Factor 2021: 8.013| ISI I.F.Value:1.241| Journal DOI: 10.36713/epra2016 ISSN: 2455-7838(Online) EPRA International Journal of Research and Development (IJRD) Volume: 6 | Issue: 12 | December 2021 \\ - Peer Reviewed Journal}

middle peasants and rich bays decreased. The number of peasant farms with 1-2 acres of land remained practically unchanged, which turned out to be the most stable in conditions of devastation.

But the deterioration of the economic situation of the Turkestan village, the increase in its structure of the number of poor people practically did not affect its internal social relations. By the time of the revolutionary events of 1917 , there were still no moods of pronounced social hatred in them, and the communal foundations and the all-encompassing influence of the religion of Islam were still strong. It was precisely the absence of acute social antagonism in the village that did not provoke a broad agrarian movement in it in 1917 and was, as the workers of the Soviet apparatus noted in the mid-1920s, the main reason due to which "during the full height of the unprecedented revolution, which fundamentally broke all the foundations of the state system and the usual way of life, the natural striving of the peasants for land did not get an outlet, did not express itself in the seizure of richpossessions, and completely unearned possessions were preserved here "[3].

The Marxist program presupposed a radical restructuring of the structure and psychology of the peasantry. The individual peasant was to disappear as a social unit of Soviet society. He was to be replaced by an agrarian worker working on large collective farms, on socialized land with socialized implements. Therefore, the entire agrarian policy of the Soviet government was aimed at the countryside and its "socialization". In general, the implementation of this program in the first years of Soviet power, its main efforts were aimed at creating socialist forms of management in the village; the formation of new social structures; strengthening social support in the face of the poorest part of dehkans, increasing their social activity; every possible limitation of the possibilities for the development of individual dekhkan farms.

Theoretically, in Turkestan, there were a number of factors that could become generative in the implementation of the Bolsheviks' program for the creation of collective farms on socialized land, make the transition from an individual farm to a collective one less painful - the small size of dekhkan farms; intensive farming; high population density; well-developed skills of collectivism, driven by communal land and water use, joint construction and renovation of irrigation systems; the widespread custom of mutual assistance and mutual assistance, etc. But, in reality, it was these factors that became the reason that the farmers of Turkestan in the first years of Soviet power remained committed to the old system of management and in their overwhelming majority did not support the measures of the Soviet government for the socialist reorganization of their labor and everyday life. The farmer preferred to stay working on his small plot of land, skillfully using every piece of it and firmly knowing that his rural community would come to his aid in difficult times. Moreover, the Soviet state during this period did little to help farmers, and the created communes and agricultural cartels were poor.

Since there were no large field-growing plantation farms in Turkestan, then in 1918-1919 mainly large orchards, vineyards, nurseries were nationalized. At the same time, along with large farms of 200-500 dess., Very often smaller land holdings of 50-70 dessiatins were nationalized [4]. In total, by the spring of 1919, 105 nationalized orchards and vineyards with an area of 3149 dessiatins were registered by the People's Commissariat for Land of the Turkic Republic [5].

The nationalization of these farms changed little in land relations in the village. Since the exploitation of orchards and vineyards required the participation of specialists and large financial costs, the government decided not to divide their land among landless peasants, but, having completely preserved it, to create large Soviet farms - state farms [6]. The lands of some field farms, nationalized in 1918-1919, were distributed by local land and water committees in the following order: first of all to communes and artels, then to landless But the deterioration of the economic situation of the Turkestan village, the increase in its structure of the number of poor people practically did not affect its internal social relations. By the time of the revolutionary events of 1917 , there were still no moods of pronounced social hatred in them, and the communal foundations and the all-encompassing influence of the religion of Islam were still strong. It was precisely the absence of acute social antagonism in the village that did not provoke a broad agrarian movement in it in 1917 and was, as the workers of the Soviet apparatus noted in the mid-1920s, the main reason due to which "during the full height of the unprecedented revolution, which fundamentally broke all the foundations of the state system and the usual way of life, the natural striving of the peasants for land did not get an outlet, did not express itself in the seizure of rich possessions, and completely unearned possessions were preserved here "[3].

The Marxist program presupposed a radical restructuring of the structure and psychology of the peasantry. The individual peasant was to disappear as a social unit of Soviet society. He was to be replaced by an agrarian worker working on large collective farms, on socialized land with socialized implements. Therefore, the entire agrarian policy of the Soviet government was aimed at of the countryside and its 


\section{SJIF Impact Factor 2021: 8.013| ISI I.F.Value:1.241| Journal DOI: 10.36713/epra2016 ISSN: 2455-7838(Online) EPRA International Journal of Research and Development (IJRD) Volume: 6 | Issue: 12 | December 2021 \\ - Peer Reviewed Journal}

"socialization". In general, the implementation of this program in the first years of Soviet power, its main efforts were aimed at creating socialist forms of management in the village; the formation of new social structures; strengthening social support in the face of the poorest part of dehkans, increasing their social activity; every possible limitation of the possibilities for the development of individual peasant farms.

Theoretically, in Turkestan, there were a number of factors that could become generative in the implementation of the Bolsheviks' program for the creation of collective farms on socialized land, make the transition from an individual farm to a collective one less painful - the small size of dekhkan farms; intensive farming; high population density; well-developed skills of collectivism, driven by communal land and water use, joint construction and renovation of irrigation systems; the widespread custom of mutual assistance and mutual assistance, etc. But, in reality, it was these factors that became the reason that the farmers of Turkestan in the first years of Soviet power remained committed to the old system of management and in their overwhelming majority did not support the measures of the Soviet government for the socialist reorganization of their labor and everyday life. The farmer preferred to stay working on his small plot of land, skillfully using every piece of it and firmly knowing that his rural community would come to his aid in difficult times. Moreover, the Soviet state during this period did little to help farmers, and the created communes and agricultural cartels were poor.

Since there were no large field-growing plantation farms in Turkestan, then in 1918-1919. mainly large orchards, vineyards, nurseries were nationalized. At the same time, along with large farms of 200-500 dess., Very often smaller land holdings of 50-70 dessiatins were nationalized [4]. In total, by the spring of 1919, 105 nationalized orchards and vineyards with an area of 3149 dessiatins were registered by the People's Commissariat for Land of the Turkic Republic [5].

The nationalization of these farms changed little in land relations in the village. Since the exploitation of orchards and vineyards required the participation of specialists and large financial costs, the government decided not to divide their land among landless peasants but, having completely preserved it, to create large Soviet farms - state farms [6]. The lands of some field farms, nationalized in 1918-1919, were distributed by local land and water committees in the following order: first of all to communes and artels, then to landless dehkans, and last of all to landless peasants, and last of all to landless dehkans.
The nationalization of the land once again emphasized the specificity of land relations in the Turkestan village and confirmed that it lacked even the very concept of the possibility of seizing foreign land. So, in the spring of 1918, many large garden farms were left without pruning, hilling, with a neglected irrigation ditch network due to the fact that their mass nationalization began when the gardens had already begun to bloom, but the owners, expecting the alienation of their possessions, did not start cultivating them, but dehkans did not even think to start spring work in them without the permission of the owners or local land and water committees [7].

From the very first days, the Soviet power in the formerly unified stratum of farmers began to form new socialist strata - workers of state Soviet farms and farmers, united into collective farms communes, artels, partnerships. As mentioned above, on the lands of most of the nationalized horticultural enterprises, state farms were organized, the workers of which were already agricultural workers.

In the same period, new, until that time unknown to farmers, economic forms in agriculture appeared in the kishlak - collective farms. The peculiarity of their creation during this period was that they were created not by order, but by a voluntary agreement of a group of individual farmers, as a rule, the poorest. The basis of their social economy was the nationalized land and implements, which the state provided them in the first place, and their own insignificant means of production, voluntarily transferred by them into collective ownership. In August 1921, 230 collective farms were counted in the Turkic Republic, uniting 16447 people and having 10155 dess. land. But all these farms had 126 plows, 264 omach, 465 horses, 735 working bulls. Comparison of the area allotted to them with the amount of available inventory and the amount of labor, testified to the fact that the labor in these collective farms was not used even by half. Therefore, in the summer of 1921, in the land authorities of the republic, an opinion appeared about the advisability of giving agricultural cartels the status of cooperatives [8].

Party and Soviet bodies in the Turkestan village were focused only on the poor, in whom they saw the social support of their power and the basis of socialist land use reorganization. The organs of Soviet power deliberately opposed the poor farmers to the diligent owners, provoking a split in the once united rural society. They urged dehkans not to pay "not a single grain, not a single kopeck" to land owners for its rent. With the permission of the authorities, the poor began to carry out requisitions and confiscations of agricultural implements, seeds, draft animals, etc. from the rich fellow villagers, to 


\section{SJIF Impact Factor 2021: 8.013| ISI I.F.Value:1.241| Journal DOI: 10.36713/epra2016 ISSN: 2455-7838(Online) EPRA International Journal of Research and Development (IJRD) Volume: 6 | Issue: 12 | December 2021 \\ - Peer Reviewed Journal}

impose significant amounts of indemnities on them. Moreover, they took indemnities and confiscated property not only from the rich beys, but also from the middle peasants, who had 5-6 dess. land.

In general, the activities of the Soviet government in the village in the first years of its formation did not contribute to the stabilization and improvement of the situation of farmers. Its such measures in 1918-1920 as the prohibition of transactions for the purchase, sale, lease of land; the use of hired labor; nationalization of enterprises in the cotton industry, oil and soap production; the introduction of the state cotton monopoly, firm purchase prices for cotton fiber; closure of bazaars; surplus appropriation; The "policy of war communism" had an extremely negative impact on the position of all individual farmers. Drought and poor harvest in 1917, famine in 1918, general devastation and instability led the agriculture of the region to disaster. In Turkestan in 1920, compared with 1917, the number of dekhkan farms decreased by almost $16 \%$, the number of rural population decreased by $20.7 \%$ [9]. Only in Tashkent uyezd during this period the number of farms renting land decreased from $6.5 \%$ to $2.6 \%$ and the number of farms renting land from $9.6 \%$ to $1.4 \%$ [10].

The social task of transferring the nomadic and semi-nomadic population to a sedentary way of life was very painfully solved in the course of the reform. The presence of this social stratum was one of the specific features of Turkestan. In 1920, there were 253.5 thousand nomadic households in the republic, which accounted for $29.5 \%$ of all dekhkan farms with a population of 1 million 231.7 thousand people, or $28.9 \%$ of rural residents. They owned 284 thousand dess. land. By 1920, compared with 1917, the number of farms decreased by $25.3 \%$, the population - by $31.3 \%$, draft animals - by $73.4 \%$, land - by $45.5 \%$ [11]. The Soviet government considered the transfer of nomadic farms to a sedentary lifestyle as a transition to a higher stage of social development. But at the same time, she did not take into account that it would be extremely painful for the nomadic population, since not just a change in economic activity will take place, but, covering all aspects of the life of the nomadic population, it will entail fundamental changes in its traditions, psychology, and professional skills. This process was all the more painful because it was carried out, like all the measures of the Soviet regime at that time, in a hurry and within the framework of another political "campaign". The land reform has provided 8.5 thousand settling Kyrgyz farms, which were allocated 143 thousand dessiatins land; 1232 farms of nomadic Kyrgyz were allotted 20.3 thousand dessiatins; land-poor Kyrgyz societies were allocated
350 thousand dessi of land for grazing livestock [12].

The reform of 1921-1922, having solved its main task, did not make significant changes in the land relations of the village. The bulk of the dehkans did not oppose the bays and did not support, in the scale expected by the authorities, the policy of limiting rich land tenure. In essence, the reform had more political than economic significance. Lowpower farms, which nevertheless received land, could not use it efficiently, since they had a very small number of draft animals and agricultural implements. They needed help, but the Soviet government was not ready for this.

In 1923, for the first time since 1916, a relatively small, but nevertheless, growth of sown areas and harvested agricultural products began in the agriculture of the republic. The cost of all agricultural products in the republic increased from 130 million rubles in 1922 up to 161 million rubles. in 1923, the total sown area increased by 632 thousand dess., the number of livestock - by more than $30 \%$. Especially noticeable shifts were in the development of cotton growing. Its sown area has increased over the years from 53 thousand hectares to 157 thousand hectares, the gross harvest - from 39 thousand tons to 111 thousand tons [13]. Cotton prices rose noticeably. In August 1923, a farmer was already given 10 arshins of chintz for a pood of cotton in Tashkent, and 13.08 arshins in Samarkand [14]. One pood of cotton in rubles cost 2 rubles. 70 . kopeck which before the war in the same equivalent cost 4 rubles. 50 kopecks. But in general, the general condition of agriculture was still difficult.

The class principle was placed at the forefront of the state cooperative policy. The Soviet government viewed cooperation as a means of involving small commodity producers in socialism, and also as a social tool for ousting the private sector. This was especially evident when admitting to a cooperative, when priority was given to the poor (well-to-do farmers had to pay as a down payment an amount 2 times higher than the contributions of the middle peasants and 12 times higher than those of the poor), as well as in issuing loans when the agricultural bank issued loans to members cooperatives at $12 \%$, and individuals - at $37-39 \%$. However, despite these negative aspects, cooperation, as a form of economic cooperation between farmers and the state, was positively perceived by the individual farmers of Turkestan.

Thus, in the early 1920s, the social structure of the village in comparison with 1917 practically did not undergo any changes agriculture was still dominated by individual small village farms. Due to the fact that the government of the Turkic Republic in the first years of Soviet power, due to the lack of 
finances and the necessary specialists, did not conduct a complete survey of the economic and social situation of the village, accurate information about its social structure in the early 1920s. But on the basis of the data of the People's Commissariat of Agriculture of the TASSR, in some districts of the Fergana and Samarkand regions, one can get an idea of the social composition of their rural population and, with a certain degree of approximation, extend it to the entire republic, since these regions had a typical structure of peasant farms for the region.

\section{CONCLUSION}

Indeed, land relations in the Turkestan village have changed little during the first years of Soviet power: the number of landless farmers remained practically the same, since the Soviet government was unable to solve the problem of allotting them land; In general, the number of middle and wealthy strata has not changed either. They continued to prove their resilience in extreme conditions.

A characteristic feature in the social relations of the village during this period were the first steps of the Soviet government to introduce socialist elements into them by the formation of new social strata - collective farmers and workers of state farms, associated with new economic sectors of the economy - collective and state farms. But there were very few of them, economically they were weak, poorly organized and did not play any significant role either in the economy of the village or in its social relations. The republic was provided with raw materials and food products by individual farmers.

\section{REFERENCES}

1. Volkov E.Z. Population dynamics of the USSR. M., 1930 .-p. 180

2. Statistical Yearbook. T. II, part 3.... - P. 113.

3. The land issue in Uzbekistan. Materials for the 2nd kurultai of the Soviets. - Samarkand, 1927. p. 11.

4. Socialist reorganization of agriculture in Uzbekistan. (1917-1926) Sat. doc. - Tashkent, 1962.T. 1. - p. 51-57, 68-69, 73-76, 83-91.

5. National Archives of Uzbekistan, fund. R-25, inventory-1, case. 225, sheet. 20.

6. National Archives of Uzbekistan, fund. R-25, inventory-1, case 35, sheet 114.

7. National Archives of Uzbekistan, fund. R-17, inventory. 1, case. 225, sheet 18-20.

8. National Archives of Uzbekistan, fund. R-29, inventory. 3, case. 2243, sheet. 4.

9. Statistical Yearbook. 1917-1923. T. II, part 3. - p. 23-25.

10. Aminova R. Agrarian policy of the Soviet government in Uzbekistan (1917-1920). Tashkent, 1962. - p. 247.
11. Statistical Yearbook. 1917-1923. T. II, part 3. p. 23-25.

12. Socialist reorganization of agriculture in Uzbekistan. 1917-1926 Sat. doc .- p. 216.

13. Cotton growing in Uzbekistan for 50 years. Tashkent, 1967.-P. 24.

14. Statistical Yearbook. 1917-1923. Vol. 1, part 1 P. 71 . 